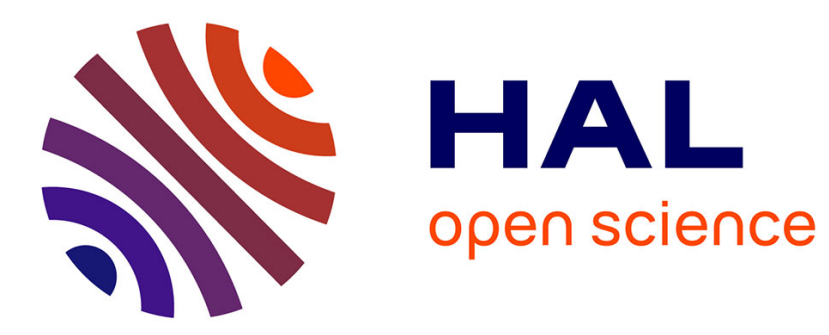

\title{
CERTAMENTE AND SICURAMENTE. ENCODING DYNAMIC AND DISCURSIVE ASPECTS OF COMMITMENT IN ITALIAN
}

Paola Pietrandrea

\section{- To cite this version:}

Paola Pietrandrea. CERTAMENTE AND SICURAMENTE. ENCODING DYNAMIC AND DISCURSIVE ASPECTS OF COMMITMENT IN ITALIAN. Belgian Journal of Linguistics, 2008, pp.221246. hal-00665192

\author{
HAL Id: hal-00665192 \\ https://hal.science/hal-00665192
}

Submitted on 1 Feb 2012

HAL is a multi-disciplinary open access archive for the deposit and dissemination of scientific research documents, whether they are published or not. The documents may come from teaching and research institutions in France or abroad, or from public or private research centers.
L'archive ouverte pluridisciplinaire HAL, est destinée au dépôt et à la diffusion de documents scientifiques de niveau recherche, publiés ou non, émanant des établissements d'enseignement et de recherche français ou étrangers, des laboratoires publics ou privés. 


\title{
CERTAMENTE AND SICURAMENTE. ENCODING DYNAMIC AND DISCURSIVE ASPECTS OF COMMITMENT IN ITALIAN
}

\author{
Paola Pietrandrea \\ Università Roma Tre
}

\begin{abstract}
Commitment should be understood as a dynamic and discursive category. This raises some important questions for the theory of grammar: to what extent do languages encode the dynamic and discursive aspects of commitment? At what level of analysis does this encoding take place? Which markers encode these aspects? In order to answer some of these questions two Italian adverbs expressing strong commitment are analyzed: certamente and sicuramente. Their distribution at the level of macro-syntactic discourse configurations is studied and contrasted. It emerges that the two adverbs select different distributional contexts. Certamente occurs in contexts that reveal its nature as a polyphonic trigger; sicuramente occurs in contexts that reveal its nature as a trigger of a paradigm of strictly internal alternative judgments. The encoding of the more discursive and dynamic aspects of commitment takes place, at least in this case, not at the morphological or at the syntactic level, but at the discourse level. Indeed, it is conveyed by the constructional composition of the lexical meaning of the two adverbs with the meaning of the discourse structures with which they are associated.
\end{abstract}

\section{Commitment and epistemic modality}

In the extensive literature on epistemic modality (Lyons 1977; Palmer 1986; Coates 1983; Nuyts 2001; Papafragou 2000; Dendale \& van der Auwera 2001; van der Auwera \& Dendale 2001; Pietrandrea 2005; Frawley 2006) commitment plays an important role. It is commonly considered as the attitudinal counterpart of epistemic modality. To cite just two authors, Lyons writes:

Any utterance in which the speaker explicitly qualifies his commitment to the truth of the proposition expressed by the sentence he utters [...] is an epistemically modal, or modalized utterance. (Lyons 1977: 797)

and Palmer:

The term epistemic should apply [...] to any modal system that indicates the degree of commitment by the speaker to what he says. (Palmer 1986: 51) 
Epistemic modality is thus viewed as the grammatical category that expresses the speaker's commitment to the truth of what he says.

In spite of the relevance of this notion, the question of what commitment is is hardly ever explicitly addressed and theorized in the studies on epistemic modality. Only a vague representation of the notion can be inferred. Commitment, indeed, is generally understood as a truth-value judgment already established in the mind of the speaker before the utterance is produced. Commitment can vary in strength: markers of strong commitment are often opposed to markers of weak commitment (Coates 1983; Palmer 1986; Pietrandrea 2005, among others). A distinction is also frequently made between a commitment justified by the speaker's personal beliefs and a commitment justified on the basis of some evidential source (Coates 1983; Pietrandrea 2005; among others).

However, more careful reflection suggests that commitment is more than this. In this respect, it is useful to turn to the elaboration of the notion of prise en charge (Laurendeau 1989; Nølke 1994; Desclés \& Guentchéva 2001; Nølke et al. 2004; Dendale \& Coltier 2006; among others), a term that literally means 'taking in charge', and which is the closest there is to a counterpart for 'commitment' in the French literature. In that tradition, commitment is not regarded as a mental state preceding the utterance act and somehow independent of it. Rather, commitment is considered to be profoundly rooted in the utterance act itself, as it is acknowledged that it can arise, grow and change during the utterance act.

As shown by Dendale \& Coltier (2006), the notion of commitment also plays an important role in some theories of 'polyphony' (Ducrot 1984, 2001; Nølke 1994; Nølke et al. 2004; also Desclés \& Guentchéva 2001; Simone 2007), i.e. those theories that regard every utterance as the layering of several voices expressing different, even contradictory, points of view ${ }^{1}$ (see Dendale 2006 for an overview). It is clear within these theories that commitment to the truth of what is said may be attributed not only to the speaker but also to other discursive voices. Besides, commitment is considered to be negotiable (see e.g. Desclés 2007). The speaker, for example, can concede or not concede the truth of a propositional content put forward by the listener or other discursive voices. The speaker can also decide to limit his commitment to only a part of what is taken in charge by others.

Finally, as pointed out by Beyssade \& Marandin (forthcoming), commitment also plays a crucial role in several formal theories of dialogue and argumentation - Hamblin (1970, 1971); Gazdar (1981); Gunlogson (2003) where it is considered a public, dialogical, retractable attitude that may serve not only to make the speaker responsible for what he says, but also to attribute to the hearer an attitude towards what is said.

To sum up, the theories just mentioned view commitment as a dynamic, discursive, often dialogical attitude. It is with the notion so understood that I will 
be concerned in this paper, rather than with the traditional understanding that emerges from the literature on epistemic modality.

\section{Some questions for the theory of grammar}

This new characterization of commitment raises some important questions for the theory of grammar in general and for a redefinition of epistemic modality in particular:

(i) To what extent do languages encode the dynamic and discursive aspects of commitment? For example, are there markers dedicated to indicating that the speaker's commitment is changing? Are there markers dedicated to encoding the fact that the speaker is committed to the truth of what is said by other discursive voices? Are there markers that indicate that the speaker is committed to the truth of what is said by others only to a certain extent?

(ii) At what level of analysis does this encoding take place? At the morphological, syntactical or discourse level?

(iii) Which markers encode these aspects? Are they lexical or grammatical markers?

In brief, the question arises: how and to what extent are the dynamic and discursive aspects of commitment grammaticalized in languages?

\section{The opposition between certamente and sicuramente in Italian}

In order to answer some of the questions raised above, two Italian adverbs expressing strong commitment and usually considered to be quasi-synonyms will be analyzed: certamente (roughly corresponding to 'certainly') and sicuramente (roughly corresponding to 'surely'). In particular, the distributional constraints on these two adverbs in discourse will be identified and contrasted.

The hypothesis behind this study is that a difference in the distributional constraints of the two adverbs may reveal some of their semantic differences (see Harris's 1968 distributional hypothesis, regarding this issue).

As is clear from the examples in (1), certamente and sicuramente do not differ in topological distribution when analyzed within the limits of the clause. Both adverbs can in fact occur at every major phrasal boundary in a sentence like Luigi è venuto 'Luigi has come':

(1) (a) Sicuramente Luigi è venuto.

(b) Certamente Luigi è venuto. 
(c) Luigi sicuramente è venuto.

(d) Luigi certamente è venuto.

(e) Luigi è venuto sicuramente.

(f) ? Luigi è venuto certamente.

(g) Luigi è venuto, certamente.

The only difference worthy of mention is the prosodic difference between (e) and (g). Example (e) shows that sicuramente can occur in the final position of a sentence entirely realized within one intonation unit. Example (f) shows that certamente cannot. ${ }^{2}$ Certamente can, indeed, occur in final position, but only if, as in (g), it is preceded by a pause. The prosodic difference between (e) and (g) reveals a difference in the macro-syntactic structure of the two utterances. ${ }^{3}$ While sentence ( $f$ ) is uttered to realize only one illocutionary act (the assertion 'Luigi has certainly come'), sentence ( $\mathrm{g}$ ) is uttered to realize two different assertions: an answer echoing another discursive voice, Luigi è venuto 'Luigi has come' and a confirmation, certamente 'this is certain'. This asymmetry shows that there exists at least one difference in the distributional constraints of the two adverbs. This difference seems to be motivated by the fact that, while certamente appears specialized in marking a particular dynamic and discursive aspect of commitment, i.e. the commitment to the truth of what has been said by other discursive voices, sicuramente does not show a similar semantic specialization.

Interestingly, the only distributional difference found so far has been detected not at the clausal, but at the supra-clausal level, namely in the macrosyntactic structure of discourse. This fact both opens a promising new route for our research and raises a methodological problem. It is highly plausible in fact that the dynamic and discursive aspects of commitment do not reveal themselves within the limits of the clause, but can be identified at a higher level, such as discourse. At the same time, however, this route ventures into a risky terrain. The question arises of how to obtain a methodologically rigorous definition of the supra-clausal contexts in which sicuramente and certamente occur.

\section{Methodology}

In order to solve our methodological problem, it is, first of all, essential to look for occurrences of the two adverbs in natural contexts. This is easily done by performing corpus searches. The present study is based on the analysis of 149 tokens of sicuramente and 101 tokens of certamente occurring in the LIP, a corpus of spoken Italian containing about 500,000 words (De Mauro et al. 1993). In order to avoid an 'oral' bias, these occurrences have been compared with a sample of 50 tokens of sicuramente and 50 tokens of certamente occurring in the la Repubblica corpus, a large database of written Italian containing about 380 million tokens (Baroni et al. 2004). 
Secondly, it is necessary to identify theoretically relevant supra-clausal units and to study how the distribution of sicuramente and certamente varies within them. Several models of semantic and pragmatic parsing of discourse have been proposed in the literature: Discourse Representation Theory (Kamp 1981; Heim 1982), Unified Linguistic Discourse Model (Polanyi 1988; Polanyi et al. 2004), Rhetorical Structure Theory (Mann \& Thompson 1988; Taboada \& Mann 2006a, 2006b), just to mention a few. Our analysis does not aim at understanding whether the two adverbs under examination occur in a given pragmatic, semantic or thematic unit of discourse, but in precisely identifying their syntactic environment. For this reason we have not resorted to the above models. Rather, mainly building on Claire Blanche-Benveniste's seminal work (Blanche-Benveniste et al. 1979; Blanche-Benveniste et al. 1990), we have adopted and extended a syntax-based approach to discourse parsing. Such an approach identifies a new level of analysis, the configuration de discours or 'discourse configuration' roughly characterizable as the maintenance of a given predicate-argument-adjunct structure in discourse.

\subsection{Discourse configurations}

In order to define discourse configurations, we assume as a primitive what Blanche-Benveniste et al. (1979) call construction maximale, i.e. the abstract predicate-argument-adjunct structure, defined on a purely syntactic base, with no reference to the semantics of phrases. The abstract predicate-argumentadjunct structure is hardly ever fully realized in a single discourse sequence. More frequently, it is gradually built by means of repetitions, additions, rewordings, and other kinds of insistence on one or more of its positions. So, for example the predicate-argument-adjunct structure in (2) may be realized as in (3) as well as in (4):

(2) $\mathrm{ADJ}_{1}-\mathrm{ARG}_{1}-\mathrm{PRE}-\mathrm{ARG}_{2}$

(3) Forse chissà io ho scelto il momento sbagliato.

'Maybe, I don't know, I have chosen the wrong moment.'

\begin{tabular}{|l||l|l|l|l||}
\hline 1 & $\begin{array}{l}\text { forse } \\
\text { 'maybe' }\end{array}$ & & & \\
\hline 2 & $\begin{array}{l}\text { chissà } \\
\text { 'I don't know' }\end{array}$ & $\begin{array}{l}\text { io } \\
\text { 'I' }\end{array}$ & $\begin{array}{l}\text { ho scelto } \\
\text { 'have chosen' }\end{array}$ & $\begin{array}{l}\text { il momento sbagliato } \\
\text { 'the wrong moment' }\end{array}$ \\
\hline & $\mathrm{ADJ}_{1}$ & $\mathrm{ARG}_{1}$ & $\mathrm{PRE}$ & $\mathrm{ARG}_{2}$ \\
\hline
\end{tabular}

(4) Magari lui rincorre un sogno, un'utopia, un ideale qualunque.

'Maybe he pursues a dream, a utopia, some sort of ideal.' 


\begin{tabular}{|c|c|c|c|c|}
\hline 1 & $\begin{array}{l}\text { magari } \\
\text { 'maybe' }\end{array}$ & $\begin{array}{l}\text { lui } \\
\text { 'he' }\end{array}$ & $\begin{array}{l}\text { rincorre } \\
\text { 'pursues' }\end{array}$ & $\begin{array}{l}\text { un sogno } \\
\text { 'a dream' }\end{array}$ \\
\hline 2 & & & & $\begin{array}{l}\text { un'utopia } \\
\text { 'a utopia' }\end{array}$ \\
\hline 3 & & & & $\begin{array}{l}\text { un ideale qualunque } \\
\text { 'an ideal whatsoever' }\end{array}$ \\
\hline & $\mathrm{ADJ}_{1}$ & $\mathrm{ARG}_{1}$ & PRE & $\mathrm{ARG}_{2}$ \\
\hline
\end{tabular}

A given predicate-argument-adjunct structure can also be instantiated more than once in discourse. For example, the spoken sequence in (5) features a repetition of the $\mathrm{ADJ}_{1}-\mathrm{ARG}_{1}-\mathrm{PRE}-\mathrm{ARG}_{2}$ structure, besides the multiple instantiations of the $\mathrm{ARG}_{1}$ and $\mathrm{ARG}_{2}$ positions:

(5) Praticamente per ogni tipo di gioco c'era un edificio specifico. Per esempio il circo serviva alle corse dei carri, l'anfiteatro alle lotte dei gladiatori, lo stadio per i giochi atletici.

'In practice, for every kind of game there was a specific building. For example the circus was for the chariot races, the amphitheatre for the gladiator fights, the stadium for athletic games.' (from Bonvino 2005: 61)

\begin{tabular}{|l||l|l|l|l||}
\hline 1 & $\begin{array}{l}\text { praticamente } \\
\text { 'in practice' }\end{array}$ & $\begin{array}{l}\text { per ogni tipo di gioco } \\
\text { 'for every kind of game' }\end{array}$ & $\begin{array}{l}\text { c'era } \\
\text { 'there was' }\end{array}$ & $\begin{array}{l}\text { un edificio specifico } \\
\text { 'a specific building' }\end{array}$ \\
\hline 2 & $\begin{array}{l}\text { per esempio } \\
\text { 'for example' }\end{array}$ & $\begin{array}{l}\text { il circo } \\
\text { 'the circus' }\end{array}$ & $\begin{array}{l}\text { serviva } \\
\text { 'was' }\end{array}$ & $\begin{array}{l}\text { alle corse dei carri } \\
\text { 'for the chariot races' }\end{array}$ \\
\hline 3 & 'the amphitheatro & $\begin{array}{l}\text { alle lotte dei gladiatori } \\
\text { 'for the gladiator fights' }\end{array}$ \\
\hline 4 & & $\begin{array}{l}\text { lo stadio } \\
\text { 'the stadium' }\end{array}$ & $\begin{array}{l}\text { per } \text { i giochi atletici } \\
\text { 'for athletic games' }\end{array}$ \\
\hline & $\mathrm{ADJ}_{1}$ & $\mathrm{ARG}_{1}$ & $\mathrm{PRE}$ & $\mathrm{ARG}_{2}$ \\
\hline
\end{tabular}

We can provisionally define a discourse configuration as the chunk made up of the sequence that instantiates or repeats a predicate-argument-adjunct structure. Given this definition, it is clear that discourse configurations can be more or less extended: whereas the discourse configurations in (3) and (4) are limited to a clause, the discourse configuration in (5) spans an entire text. What is more, discourse configurations can sometimes be the result of dialogical cooperation between two or more speakers. We have an example in (6):

(6) A: Luigi mi guarda sempre con amore.

B: o con compassione!

A: 'Luigi always looks at me with love.'

B: 'or with compassion!' 


\begin{tabular}{|c|c|c|c|c|c|c|}
\hline 1 & A: & $\begin{array}{l}\text { Luigi } \\
\text { 'Luigi' }\end{array}$ & $\begin{array}{l}\text { mi guarda } \\
\text { 'looks at me' }\end{array}$ & $\begin{array}{l}\text { sempre } \\
\text { 'always' }\end{array}$ & & $\begin{array}{l}\text { con amore } \\
\text { 'with love' }\end{array}$ \\
\hline 2 & B: & & & & $\begin{array}{l}\text { o } \\
\text { 'or' }\end{array}$ & $\begin{array}{l}\text { con compassione } \\
\text { 'with compassion' }\end{array}$ \\
\hline & & $\mathrm{ARG}_{1}$ & $\mathrm{PRE}_{1}$ & $\mathrm{ADJ}_{1}$ & CONJ & $\mathrm{ADJ}_{2}$ \\
\hline
\end{tabular}

We can thus define a 'discourse configuration' (henceforth $D C$ ) as the monological or dialogical chunk made up of the sequence that instantiates or repeats a predicate-argument-adjunct structure.

According to this definition, two different DCs can be recognized in (7). The first one twice instantiates the structure $A R G_{1}-P R E-A R G_{2}$, the second one twice instantiates the structure $\mathrm{ARG}_{1}-\mathrm{ADJ}_{1}$-PRE.

(7) Gli ho detto che è l'ultimo della lista, che è insopportabile, gli ho detto basta. Lui comunque va all'attacco, lui comunque si appassiona.

'I told him he is the last on my list, he is unbearable, I told him it's over. Anyway, he goes on the attack, anyway he gets impassioned.'

\begin{tabular}{|l||l|l|l||}
\hline 1 & $\begin{array}{l}\text { gli } \\
\text { 'to him' }\end{array}$ & $\begin{array}{l}\text { ho detto } \\
\text { 'I said' }\end{array}$ & $\begin{array}{l}\text { che è l'ultimo della lista } \\
\text { 'the he is the last on my list' }\end{array}$ \\
\hline 2 & & $\begin{array}{l}\text { che è insopportabile } \\
\text { 'that he is unbearable' }\end{array}$ \\
\hline 3 & $\begin{array}{l}\text { gli } \\
\text { 'to him' }\end{array}$ & $\begin{array}{l}\text { ho detto } \\
\text { 'I said' }\end{array}$ & $\begin{array}{l}\text { basta } \\
\text { 'it's over' }\end{array}$ \\
\hline & $\mathrm{ARG}_{1}$ & PRE & $\mathrm{ARG}_{2}$ \\
\hline
\end{tabular}

\begin{tabular}{|l||l|l|l||}
\hline 1 & $\begin{array}{l}\text { lui } \\
\text { 'he' }\end{array}$ & $\begin{array}{l}\text { comunque } \\
\text { 'anyway' }\end{array}$ & $\begin{array}{l}\text { va all'attacco } \\
\text { 'goes on the attack' }\end{array}$ \\
\hline 2 & $\begin{array}{l}\text { lui } \\
\text { 'he' }\end{array}$ & $\begin{array}{l}\text { comunque } \\
\text { 'anyway' }\end{array}$ & $\begin{array}{l}\text { si appassiona } \\
\text { 'gets impassioned' }\end{array}$ \\
\hline & $\mathrm{ARG}_{1}$ & $\mathrm{ADJ}_{1}$ & PRE \\
\hline
\end{tabular}

The DCs from (3) through (7) are represented in 'grids', i.e. through a rewriting procedure elaborated mainly by Blanche-Benveniste et al. (1979), Bilger (1982), Blanche-Benveniste et al. (1990), Bilger et al (1997), Duvallon (2006), and Bonvino (2005) and Masini \& Pietrandrea (submitted) for Italian. This rewriting procedure consists in a representation of the speech flow on a bi-dimensional plane and is constrained by three simple rules: (i) the horizontal axis of the plane should feature the sequence of the positions that define the predicate-argumentadjunct structure; (ii) the vertical axis should list all the actual realizations within each position; (iii) a left-to-right and top-down reading of the string contained in the grid should render the linear order of the represented chunk. ${ }^{4}$

This representation highlights the fact that DCs can be described on the basis of their shape, i.e. on the basis of what we call their 'topological structure'. Such 
a topological structure can be described by referring to a number of 'topological patterns': lists of elements in the same position, repetitions of syntactic structures, chiastic elements shifting from a pre-verbal to a post-verbal position (or vice versa), dialogical completions and so on. ${ }^{5}$

The body of research carried out on DCs has shown that certain topological structures regularly recur both in spoken (Blanche-Benveniste 1990; BlancheBenveniste et al. 1997) and in written language (Branca-Rosoff 1990). Interestingly for our purposes, it has been argued that certain topological patterns may have very abstract meanings (Blanche-Benveniste 1993; Bonvino 2005; Bonvino \& Masini 2007). It has also been shown that there are adverbs which are regularly associated with certain DCs characterized by specific topological patterns and that they occupy specific positions within those patterns (Bonvino et al. 2007; Pietrandrea 2007; Masini \& Pietrandrea in preparation). The analysis of the composition of the meaning of these adverbs with the meaning of the topological patterns with which they are associated has provided some valuable insights for a semantic definition of the adverbs in question.

Using DCs in the analysis of adverbs therefore constitutes a promising methodological approach towards:

- a syntactic parsing of discourse and the consequent identification of the relevant units of analysis, even if dialogically built;

- the univocal identification of the position occupied by the adverb within the unit of analysis;

- the analysis of the semantic contribution of the adverb to the overall constructional meaning of the DC.

Such a methodology therefore appears particularly suitable for our purposes. A caveat should be mentioned, however. Very frequently certamente and sicuramente are not integrated within the predicate-argument-adjunct structure. They often modify nominal utterances, as in (8) and (9); they often constitute holophrastic utterances, as in (10) and (11):

(8) Certamente no. 'Certainly not.'

(9) Sicuramente meno di due. 'Certainly [lit. surely] less than two.'

(10) Non la conosci. Certamente. 'You don't know her. This is certain [lit. certainly].'

(11) Mai rispettata. No. Si. Sicuramente.

'Never respected. No. Yes. Surely.'

An extension of the notion of discourse configuration is therefore required. 


\subsection{Macro-syntax and macro-syntactic discourse configurations}

The dependency relations internal to the predicate-argument-adjunct structure are not the only kind of relations that obtain within utterances. Many scholars (Blanche-Benveniste et al. 1990; Berrendonner 1990; Cresti 2000; Andersen \& Nølke 2002) have worked out a description of a new level of syntactic structure, the so-called macro-syntax. At this level, every utterance can be analyzed into one or more prosodically marked information units fulfilling different informational functions.

The central indispensable information unit is the so-called NUCLEUS, the 'core' of the utterance, which is a potentially autonomous unit that confers to the utterance the illocutionary force of for example an assertion, a question, an exclamation, or an order (Cresti 2000). To give an example, in (12B), the unit 'John has come back' is the only prosodic unit endowed with an autonomous illocutionary force; it could be recognized as an assertion even if uttered in isolation. It can therefore be easily identified as the NUCLEUS of the utterance.

(12) A: What happened?

B: $[\text { As expected }]_{\text {PREFIX }}[\text { John has come back }]_{\text {NUCLEUS }}[\text { yesterday }]_{\text {SUFFFIX }}$.

Other macro-syntactic units, lacking illocutionary force, are recognized and classified by macro-syntacticians according to their position with respect to the NUCLEUS. We will focus our attention on macro-syntactic PREFIXES and macrosyntactic SUFFIXES.

A macro-syntactic PREFIX is the prosodic unit preceding the NUCLEUS. This unit can fulfil various functions, such as introducing the NUCLEUS (Muller 2002), providing a stance on it or establishing the field of application of what is predicated in the NUCLEUS (Blanche-Benveniste et al. 1990). In (12B), for example, the PREFIX can be identified with the unit as expected. This unit could not be attributed an illocutionary force if uttered in isolation. It merely serves to provide a stance on the NUCLEUS John has come back.

A macro-syntactic SUFFIX is the prosodic unit following the NUCLEUS. This unit can be occupied by adverbial propositions, appositions and afterthoughts, usually uttered with a flat intonational profile (Blanche-Benveniste et al. 1990, Cresti 2000). In (8) the SUFFIX can be identified with the unit yesterday, which is uttered after a pause, lacks illocutionary autonomy and expresses an afterthought.

To sum up, building on Cresti (2000), Blanche-Benveniste et al. (1990) and Blanche-Benveniste (2002), we suggest that, independently of its syntactic structure, every utterance realizes a 'macro-syntactic structure', i.e. a sequence of macro-syntactic units, centered around one and the same NUCLEUS and therefore endowed with a unitary illocutionary force.

On this basis, we propose that the discourse configurations we have already partially characterized in $\$ 4.1$ should be centered not only around a predicateargument-adjunct structure, but also around a macro-syntactic structure. Thus, 
two different macro-syntactic discourse configurations can be recognized in (13), the first one instantiating the macro-syntactic structure PREFIX-NUCLEUS, the second one the structure NUCLEUS-SUFFIX:

(13) Luigi verrà, Mario non ci sarà e gli altri non so. Non chiedermi altro per favore.

'Luigi will come, Mario won't be there, I do not know about the others. Please, don't ask me anything else.'

\begin{tabular}{|l||l|l||}
\hline 1 & $\begin{array}{l}\text { Luigi } \\
\text { 'Luigi' }\end{array}$ & $\begin{array}{l}\text { verrà } \\
\text { 'will come' }\end{array}$ \\
\hline 2 & $\begin{array}{l}\text { Mario } \\
\text { 'Mario' }\end{array}$ & $\begin{array}{l}\text { non ci sarà } \\
\text { 'won't be there' }\end{array}$ \\
\hline & $\begin{array}{l}\text { gli altri } \\
\text { 'the others' }\end{array}$ & $\begin{array}{l}\text { non so } \\
\text { 'I don't know' }\end{array}$ \\
\hline \multicolumn{2}{|l|}{ PREFIX } & NUCLEUS \\
\hline \multirow{2}{*}{1} & $\begin{array}{l}\text { non chiedermi altro } \\
\text { 'don't ask me anything else' }\end{array}$ & $\begin{array}{l}\text { per favore } \\
\text { 'please' }\end{array}$ \\
\hline & NUCLEUS & SUFFIX \\
\hline
\end{tabular}

Just like DCs, macro-syntactic discourse configurations can either be monologically constructed by the speaker or result from the dialogical cooperation between two or more speakers.

We can thus define a 'macro-syntactic discourse configuration' (henceforth $M D C$ ) as the monological or dialogical chunk made up of the sequence that instantiates or repeats a macro-syntactic structure.

Since certamente and sicuramente are often not integrated within clausal syntax, we will adopt MDCs as the units of analysis relevant for our research. It must be said that, as expected, given the quasi-synonymy of certamente and sicuramente, we have found that the two adverbs are frequently associated with the same MDCs. Nevertheless, we have also found some MDCs that licence one of the two adverbs and clash with the other. To put it in another way, we have found some differences in the distributional constraints that certamente and sicuramente are subject to at the level of MDCs. According to our initial distributional hypothesis, these differences may tell us something about the semantic differences between the two adverbs. These differences are therefore the focus of our analysis. 


\section{Certamente}

\subsection{NUCLEUS position in dialogical lists of NUCLEI}

Certamente can occur in dialogical MDCs characterized by lists of nuclei. In these MDCs certamente realizes a confirmative NUCLEUS that immediately precedes or follows a NUCLEUS in which the speaker literally (or almost literally) repeats the content of a NUCLEUS uttered by his interlocutor. Let us consider (14):

(14) A: Le maiuscole non le scriveva.

B: Non le scriveva. Certamente.

A: 'Capital letters he couldn't write down.'

B: 'He couldn't. Sure [lit. certainly].'

In this sequence, speaker A utters a NUCLEUS-line1: non le scriveva 'he couldn't write them down'. This nucleus is literally repeated in NUCLEUS-line 2 by speaker B, who adds to his repetition the adverb certamente. This adverb is uttered after a pause: it therefore constitutes an autonomous information unit. This information unit is endowed with an autonomous illocutionary force. In other words it could be interpreted as a confirmative assertion even if uttered in isolation. As such it is to be considered as a third nucleus having the illocutionary force of a confirmative assertion. The sequence (14) therefore constitutes a MDC that can be represented as follows:

(14')

\begin{tabular}{|c|c|c|c|}
\hline 1 & A: & $\begin{array}{l}\text { le maiuscole } \\
\text { 'capital letters' }\end{array}$ & $\begin{array}{l}\text { non le scriveva } \\
\text { 'he couldn't write them' }\end{array}$ \\
\hline 2 & \multirow[t]{2}{*}{ B: } & & $\begin{array}{l}\text { non le scriveva } \\
\text { 'he couldn' write them' }\end{array}$ \\
\hline 3 & & & $\begin{array}{l}\text { certamente } \\
\text { 'certainly' }\end{array}$ \\
\hline & & PREFIX & NUCLEUS \\
\hline
\end{tabular}

As shown in (15) and (16) the repetition of the NUCLEUS uttered by the first speaker may also be non literal. In (15) for example, speaker B says: anche per gli studenti 'also for the students' (NuCLEUS-line3), speaker A repeats and alters this to: anche da parte degli studenti 'also of the students' (NuCLEUS-line3). In (16) speaker B says: è di commerciabilità 'it is a matter of sellability' (Nucleus-line3), and A repeats and expands: è di commerciabilità del bene 'it is a matter of the sellability of the goods' (NucLEUS-line5). Examples (15) and (16) also show that certamente can not only follow, but also precede, the repetition of what has been said by the previous speaker. 
(15) A: Ci sarà un problema di riadattamento.

B: non soltanto per i professori. Anche per gli studenti.

A: Certamente. Anche da parte degli studenti.

A: 'There will be a problem of readaptation.'

B: 'Not only for the professors, also for the students.'

A: 'Of course [lit. certainly]. Also of the students.'

\begin{tabular}{|r||l|l||}
\hline 1 & A: & $\begin{array}{l}\text { ci sarà un problema di riadattamento } \\
\text { 'there will be a problem of readaptation' }\end{array}$ \\
\hline 2 & \multirow{2}{*}{ B: } & $\begin{array}{l}\text { non soltanto per i professori } \\
\text { 'not only for the professors' }\end{array}$ \\
\cline { 1 - 1 } & & $\begin{array}{l}\text { anche per gli studenti } \\
\text { 'also for the students' }\end{array}$ \\
\hline 4 & \multirow{2}{*}{$\mathbf{A :}$} & $\begin{array}{l}\text { certamente } \\
\text { 'certainly' }\end{array}$ \\
\hline 5 & & $\begin{array}{l}\text { anche da parte degli studenti } \\
\text { 'also of the students' }\end{array}$ \\
\hline & & NUCLEUS \\
\hline
\end{tabular}

(16) A: Ma questo non è un problema di locazione.

B: Certo. Caso mai è di commerciabilità.

A: Certamente. Caso mai è di commerciabilità del bene.

A: 'but this is not matter of location.'

B: 'of course! Rather it is matter of sellability.'

A: 'sure [lit. certainly]! Rather it is matter of the sellability of the goods.'

\begin{tabular}{|c|c|c|c|}
\hline 1 & A: & $\begin{array}{l}\text { ma questo } \\
\text { 'but this one' }\end{array}$ & $\begin{array}{l}\text { non è un problema di locazione } \\
\text { 'is not a problem of location' }\end{array}$ \\
\hline 2 & \multirow[t]{2}{*}{ B: } & & $\begin{array}{l}\text { certo } \\
\text { 'of course' }\end{array}$ \\
\hline 3 & & $\begin{array}{l}\text { caso mai } \\
\text { 'rather' }\end{array}$ & $\begin{array}{l}\text { è di commerciabilità } \\
\text { 'it is a matter of sellability' }\end{array}$ \\
\hline 4 & \multirow[t]{2}{*}{ A: } & & $\begin{array}{l}\text { certamente } \\
\text { certainly }\end{array}$ \\
\hline 5 & & $\begin{array}{l}\text { caso mai } \\
\text { 'rather' }\end{array}$ & $\begin{array}{l}\text { è di commerciabilità del bene } \\
\text { 'it is a matter of the sellability of the goods' }\end{array}$ \\
\hline & & PREFIX & NUCLEUS \\
\hline
\end{tabular}

In these MDCs, certamente marks the speaker's strong commitment to what has been said by his interlocutor. This meaning is the result of the composition of the meaning of certamente with the meaning inherent in the topological structure that characterizes (14'), (15) and (16). MDCs such as (14'), (15) and (16) are all characterized by a dialogical list of NUCLEI, that is by a list of NUCLEI 
cooperatively built by two or more speakers. One of the elements of such a list is realized by a nucleus in which the speaker (almost) literally repeats the content of another NUCLEUS previously uttered by his interlocutor. Such a repetition has per se the function of marking a commitment to the truth of what has been said by another. Certamente fulfils the function of indicating that this commitment is strong. ${ }^{6}$

The fact that certamente marks a strong commitment, however, is not sufficient to explain the possibility of its use in these MDCs. Another marker of strong commitment, such as sicuramente, cannot, in fact, fulfil the same function: if used within the MDC in question it would clash. A sequence like (17), for example, is unacceptable:

(17) A: Le maiuscole non le scriveva.

$\mathrm{B}$ : *Non le scriveva, sicuramente.

To sum up, certamente, unlike sicuramente, can realize a NUCLEUS either preceding or following another NUCLEUS in which the speaker literally (or almost literally) repeats the content of a NUCLEUS uttered by his interlocutor. In this MDC, certamente marks the strong commitment of the speaker to the truth of what has been said by his interlocutor.

\subsection{NUCLEUS position in monological polyphonic lists of NUCLEI}

Certamente can also occur in monological MDCs characterized by lists of NUCLEI. In these MDCs certamente realizes a confirmative NUCLEUS, which follows another NUCLEUS that expresses the point of view of a discursive voice other than the speaker. I will call such contexts 'monological polyphonic lists of NUCLEI': they are monological because they are uttered by only one speaker, they are polyphonic because they express the point of view of a discursive voice other than the speaker. Let us examine example (18):

(18) Abbiamo commesso degli errori. Certamente. E però abbiamo vinto. 'We made some mistakes. That's for sure [lit. certainly]. Nevertheless we won.'

\begin{tabular}{|l||l|l||}
\hline 1 & & $\begin{array}{l}\text { abbiamo commesso degli errori } \\
\text { 'we made some mistakes' }\end{array}$ \\
\hline 2 & & $\begin{array}{l}\text { certamente } \\
\text { 'certainly' }\end{array}$ \\
\hline 3 & $\begin{array}{l}\text { e però } \\
\text { 'adv] } \\
\text { 'and nevertheless' }\end{array}$ & $\begin{array}{l}\text { abbiamo vinto } \\
\text { 'we won' }\end{array}$ \\
\hline & PREFIX & NUCLEUS \\
\hline
\end{tabular}

The speaker utters a NUCLEUS-line1 abbiamo commesso degli errori 'we made some mistakes', immediately followed by a NUCLEUS-line 2 realized by 
certamente, which has the illocutionary force of a confirmation. A NUCLEUSline3 follows, which is introduced by an adversative PREFIX-line3. As for the first two lines, this MDC recalls the MDC described in $\$ 5.1$. The only difference is that the NUCLEUS preceding certamente (NUCLEUS-line1) is not the actual dialogical repetition of what has been said by someone else. However it does polyphonically represent the point of view of a discursive voice other than the speaker. The presence of certamente in NUCLEUS-line 2 in fact imposes a reinterpretation of the content of NUCLEUS-line1 in which this content cannot be considered as the speaker's own point of view, but should be interpreted as a report of what has been said (or may have been said) by another unmentioned discursive voice. Uttering certamente the speaker does two things: he strongly commits to the truth of what is said in NUCLEUS-linel and he attributes NUCLEUS-line1 to another discursive voice.

This polyphonic reinterpretation, together with the adversative PREFIX introducing the speaker's own point of view in NUCLEUS-line3, allows interpreting the overall MDC as a concessive construction (Nølke \& Olsen 2000).

Interestingly, as we will see, sicuramente would clash with such a MDC. A sequence like (19), for example, is unacceptable:

(19) * Abbiamo commesso degli errori, sicuramente. E però abbiamo vinto.

\subsection{PREFIX position in monological polyphonic lists of NUCLEI}

The examples above suggest that certamente should be treated as a marker of agreement. However, the picture is more complex. Certamente in fact can also occur in MDCs in which it realizes a PREFIX introducing a NUCLEUS belonging to a list of at least two monological NUCLEI presenting the same syntactic structure. Let us examine example (20) below.

(20) Forse fu colpa degli insegnanti, che non seppero appassionarmi. Certamente fu colpa mia, che non studiavo abbastanza.

'Maybe it was the fault of the teachers who could not stir passion in me. Certainly it was my fault, as I did not [lit. 'who did not'] study enough.'

The MDC is made up of two repetitions of the macro-syntactic structure PREFIXNUCLEUS-SUFFIX. The PREFIX position is realized in one case by the adverb forse and in the other case by certamente. The NUCLEUS position is realized in one case by the predicate fu colpa degli insegnanti 'it was the fault of the teachers' and in the other case, by the predicate fu colpa mia 'it was my fault'. The SUFFIX position is realized by the two appositive relative clauses che non seppero appassionarmi 'who could not stir passion in me' and che non studiavo abbastanza 'who did not study enough'. Interestingly, not only the macrosyntactic structure, but also the predicate-adjunct-argument structure ADJ-PRE- 
ARG-ADJ is fully instantiated twice in this MDC. The MDC in (20), therefore, can be represented as in $\left(20^{\prime}\right):^{7}$

$\left(20^{\prime}\right)$

\begin{tabular}{|l||l|l|l|l||}
\hline 1 & $\begin{array}{l}\text { forse } \\
\text { 'maybe' }\end{array}$ & $\begin{array}{l}\text { fu colpa } \\
\text { 'it was the fault' }\end{array}$ & $\begin{array}{l}\text { degli insegnanti } \\
\text { 'of the teachers' }\end{array}$ & $\begin{array}{l}\text { che non seppero appassionarmi } \\
\text { 'who could not stir passion in me' }\end{array}$ \\
\hline 2 & $\begin{array}{l}\text { certamente } \\
\text { 'certainly' }\end{array}$ & $\begin{array}{l}\text { fu colpa } \\
\text { 'it was the fault' }\end{array}$ & $\begin{array}{l}\text { mia } \\
\text { 'of mine' }\end{array}$ & $\begin{array}{l}\text { che non studiavo abbastanza } \\
\text { 'who did not study enough' }\end{array}$ \\
\hline & $\mathrm{ADJ}_{1}$ & PRE & $\mathrm{ARG}_{1}$ & $\mathrm{ADJ}_{2}$ \\
\hline & PREFIX & NUCLEUS & SUFFIX \\
\hline
\end{tabular}

In this MDC certamente does not indicate strong agreement, but a contrast between the point of view of the speaker 'it was my fault' (NUCLEUS-line2) and the point of view of another discursive voice 'it was the fault of the teachers' (NUCLEUS-line1). The overall meaning of this MDC results from the composition of the meaning of certamente with the meaning inherent in the topological structure of (20'). The MDC in (20') is characterized by a repetition of the same predicate-argument-adjunct structure instantiated by (at least partially) different lexical material. As shown by Blanche-Benveniste (1997), this kind of repetition encodes a contrast per se. The presence of certamente in this discourse configuration turns the contrast between two different propositions into a contrast between two different discursive voices. Just as in the MDC described in $\$ 5.2$, certamente fulfils two functions. It both marks the speaker's strong commitment to the truth of the content of NUCLEUS-line 2 and it attributes the point of view of NUCLEUS-line1 to a discursive voice other than the speaker. An analogous example is (21):

(21) Io mi sbaglierò, ma certamente tu non sei nel giusto.

'I might be wrong. But you are certainly not right.'

\begin{tabular}{|l|l|l|l||}
\hline 1 & & $\begin{array}{l}\text { io } \\
\text { 'I' }\end{array}$ & $\begin{array}{l}\text { mi sbaglierò } \\
\text { 'might be wrong' }\end{array}$ \\
\hline 2 & $\begin{array}{l}\text { ma certamente } \\
\text { 'but certainly' }\end{array}$ & $\begin{array}{l}\text { tu } \\
\text { 'you' }\end{array}$ & $\begin{array}{l}\text { non sei nel giusto } \\
\text { 'are not right' }\end{array}$ \\
\hline & & ARG $_{1}$ & PRE \\
\hline & PREFIX & \multicolumn{2}{|l|}{ NUCLEUS } \\
\hline
\end{tabular}

The fact that certamente occurs not only in contexts of agreement, but also in contexts where conflicting views are expressed, demonstrates that rather than a marker of strong agreement, certamente marks the presence of other discursive voices. In other terms, it is a polyphonic trigger.

Interestingly, sicuramente can occur in a MDC such as that represented in (20') and (21), but without transforming the contrast between propositions into a 
contrast between discursive voices. For example in (22) the NUCLEUS 'it was the fault of the teachers' cannot be considered to express the point of view of another discursive voice, but has to be interpreted as reflecting the speaker's own point of view (see below).

(22) Forse fu colpa degli insegnanti che non seppero appassionarmi. Sicuramente fu colpa mia che non studiavo abbastanza.

Sicuramente indeed clashes with variants of the MDC in which the existence of another discursive voice is overtly mentioned - compare (23) with (24):

(23)? Forse - come dicono - fu colpa degli insegnanti che non seppero appassionarmi. Sicuramente fu colpa mia che non studiavo abbastanza. 'Maybe - as they said - it was the fault of the teachers who could not stir passion in me. Surely it was my fault, as I did not study enough.'

(24) Forse - come dicono - fu colpa degli insegnanti che non seppero appassionarmi. Certamente fu colpa mia che non studiavo abbastanza. 'Maybe - as they said - it was the fault of the teachers who could not stir passion in me. Certainly it was my fault, as I did not study enough.'

To sum up, certamente can realize a PREFIX introducing a NUCLEUS belonging to a list of two contrasting monological NUCLEI exhibiting the same syntactic structure. In this MDC certamente fulfils two functions. It marks the speaker's strong commitment to the content of the NUCLEUS it introduces and it attributes the point of view expressed in the other NUCLEUS to another discursive voice. The overall effect is a contrast between the speaker's point of view and that of the other discursive voice. When sicuramente occurs in such a MDC, the contrast marked by the repetition of the syntactic structure is naturally still there. However, sicuramente marks it as a contrast of alternative possible epistemic values given by the same discursive voice, rather than a contrast between different discursive voices. This point will be made clearer in $\S 6$.

\subsection{The reportive value}

The analysis conducted so far indicates that certamente should be understood as a trigger of polyphony. The examples from (25) to (28) confirm this intuition. In (25) certamente marks the fact that the certainty of the propositional content is based on a reported source rather than on the speaker's personal beliefs. By contrast, sicuramente in (26) marks the fact that the certainty of the propositional content is based on the speaker's beliefs. 
(25) A New York vedranno $i$ loro colleghi tra $i$ quali certamente il procuratore Giuliani e il suo assistente David Denton.

'In New York they will see their colleagues, among whom certainly Attorney General Giuliani and his assistant David Denton.'

(26) A New York vedranno i loro colleghi tra $i$ quali sicuramente il procuratore Giuliani e il suo assistente David Denton.

'In New York they will see their colleagues, among whom certainly [lit. surely] Attorney General Giuliani and his assistant David Denton.'

The explicit mention of a reported source (the press release) is compatible with certamente, but not with sicuramente. This is proved by the tests in (27) and (28).

(27) Secondo il dispaccio, a New York vedranno i loro colleghi tra $i$ quali certamente il procuratore Giuliani e il suo assistente David Denton.

'According to the press release, in New York they will see their colleagues, among whom certainly Attorney General Giuliani and his assistant David Denton.'

(28) ? Secondo il dispaccio, a New York vedranno i loro colleghi tra i quali sicuramente il procuratore Giuliani e il suo assistente David Denton.

'According to the press release, in New York they will see their colleagues, among whom certainly [lit. surely] Attorney General Giuliani and his assistant David Denton.'

On the other hand the explicit mention of the speaker's personal belief is compatible with sicuramente (29), but not with certamente (30):

(29)? Secondo me, a New York vedranno $i$ loro colleghi tra $i$ quali certamente il procuratore Giuliani e il suo assistente David Denton. 'In my opinion, in New York they will see their colleagues, among whom certainly Attorney General Giuliani and his assistant David Denton.'

(30) Secondo me, a New York vedranno $i$ loro colleghi tra $i$ quali sicuramente il procuratore Giuliani e il suo assistente David Denton.

'In my opinion, in New York they will see their colleagues, among whom certainly [lit. surely] Attorney General Giuliani and his assistant David Denton.'

Certamente thus has a reportive meaning, which is not encoded in sicuramente.

\subsection{A polyphonic trigger}

To sum up this section, certamente can occur in three different polyphonic MDCs: it can realize a NUCLEUS position in dialogical lists of NUCLEI, it can realize a NUCLEUS position in monological polyphonic lists of NUCLEI and it can realize a PREFIX introducing a NUCLEUS that belongs to a monological polyphonic lists of NUCLEI. Sicuramente clashes with all these MDCs. 
Furthermore, in some contexts certamente can acquire a reportive value, while sicuramente cannot. This provides enough evidence to maintain that certamente, unlike sicuramente, is not only a marker of strong commitment, but also a polyphonic trigger: it both marks the strong commitment of the speaker to the propositional content in its scope and it attributes that content to a discursive voice other than the speaker.

\section{Sicuramente}

\subsection{Final position in monological monophonic lists of NUCLEI}

Sicuramente can occupy the final position in monological lists of NUCLEI. Let us consider examples (31) and (32).

(31) Dall'anno prossimo sarà aiutato. Sicuramente.

'Starting next year he will be helped. It is sure [lit. surely].'

\begin{tabular}{|l||l||}
\hline 1 & $\begin{array}{l}\text { dall'anno prossimo sarà aiutato } \\
\text { 'starting next year he will be helped' }\end{array}$ \\
\hline 2 & $\begin{array}{l}\text { sicuramente } \\
\text { 'surely' }\end{array}$ \\
\cline { 2 - 2 } & NUCLEUS \\
\hline
\end{tabular}

(32) A: Ci servirà il lettino?

B: Non lo so. Forse. Ma si. Sicuramente.

A: 'Do we need the child's bed?'

B: 'I do not know. Maybe. But yes. Sure [lit. surely].'

\begin{tabular}{|c|c|c|}
\hline 1 & A: & $\begin{array}{l}\text { ci servirà il lettino? } \\
\text { 'do we need the child's bed?' }\end{array}$ \\
\hline 2 & \multirow[t]{4}{*}{ B: } & $\begin{array}{l}\text { non lo so } \\
\text { 'I don't know' }\end{array}$ \\
\hline 3 & & $\begin{array}{l}\text { forse } \\
\text { 'maybe' }\end{array}$ \\
\hline 4 & & $\begin{array}{l}\text { ma sì } \\
\text { 'but yes' }\end{array}$ \\
\hline 5 & & $\begin{array}{l}\text { sicuramente } \\
\text { 'surely' }\end{array}$ \\
\hline & & NUCLEUS \\
\hline
\end{tabular}

In (31) the speaker utters a NUCLEUS-linel containing the assertion dall'anno prossimo sarà aiutato 'starting next year he will be helped'. This assertion is judged as certain in the next NUCLEUS-line2, represented by sicuramente. In 
(32), answering the question asked by A, speaker B utters three different NUCLEI: Non lo so 'I don't know' (NUCLEUS-line2), forse 'maybe' (NUCLEUSline3) and $m a$ si 'but yes' (NUCLEUS-line4). He then concludes with a fourth NUCLEUS-line5 represented by sicuramente that serves to mark finally as certain an answer that had been put forward as not certain in the previous NUCLEI.

It should be noted that in these MDCs the commitment to the judgment progresses at each NUCLEUS. It always culminates with sicuramente occupying the final NUCLEUS position, which marks a commitment to the certainty of the judgment.

The fact that sicuramente marks a strong commitment is not sufficient to explain its occurrence in such a MDC. Indeed a marker of strong commitment such as certamente would be unsuitable in the same context. A sequence like (33), for example, is unacceptable:

(33) A: Ci servirà il lettino?

B: *Non lo so. Forse. Ma si. Certamente.

To sum up, sicuramente, unlike certamente, can occupy the final NUCLEUS position in monophonic monological MDCs characterized by lists of NUCLEI. In these MDCs, the commitment to the certainty of the judgment progresses at each NUCLEUS. Sicuramente, in final NUCLEUS position, expresses the fact that having explored a list of alternative weaker judgments, the speaker finally reaches a commitment to the certainty of his own judgment.

\subsection{Syntactic focus position}

The distributional behaviour of sicuramente distinguishes this adverb from many other phrasal adverbs. Sicuramente, in fact, can occur in the syntactic focus position, which in Italian is the sentence final position (Cinque, 1993). The utterances from (34) through (36), for example, are grammatical:

(34) $[\text { Ma si }]_{\mathrm{PREFIX}},\left[\text { l'hai visto sicuramente } \text { FOC }_{\text {! }}\right]_{\text {NUCLEUS }}$ 'Of course, you definitely saw him [lit. You saw him surely]'

(35) $[\text { Al British }]_{\text {PREFIX }}\left[\text { lo trova sicuramente } \text { FOC }_{\text {I }} !\right]_{\text {NUCLEUS }}$ 'At the British (centre), you will definitely find it [lit. You will find it surely]'

(36) $[\text { Eh no }]_{\text {PREFIX, }}$ [lo faccio sicuramente FOC $\left._{\text {! }}\right]_{\text {NUCLEUS }}$ 'No! I will definitely do that [lit. I will do that surely]'

It is widely acknowledged that every focalization evokes a paradigm of alternative options (Nølke 2001: 92; Rooth 1992). It may be argued therefore that the presence of sicuramente in focus position triggers a contrast with other weaker, not explicitly expressed judgments with scope on the same propositional content. For example, the presence of sicuramente in focus position in (36), not only marks the fact that the speaker is strongly committed 
to what he says, but it also evokes a contrast with a paradigm of other possible judgments, like 'perhaps I will do that' or 'it is unlikely that I will do that'.

It is clear that the mechanism of excluding alternative judgments that operates in this clausal construction is the same we have seen in the discourse configuration examined in $\S 6.1$. The only difference is that the mechanism of exclusion, which is vertically built in discourse, is horizontally arranged at the clausal level.

As already pointed out in (1), certamente cannot occur in syntactic focus position. The sequence in (37), for example, is ungrammatical:

(37) * Luigi è venuto certamente.

'Luigi has come back certainly.'

To sum up, sicuramente, unlike certamente, can occur in syntactic focus position. In this construction it marks a strong commitment to the truth of the propositional content and at the same time it triggers a contrast with other weaker, not explicitly expressed judgments with scope on the same propositional content.

\subsection{The type PREFIX - [sicuramente $]_{\text {NUCLEUS }}$}

An instantiation of the construction described in the previous section is the type PREFIX - [sicuramente $]_{\text {NUCLEUS }}$ exemplified in utterances (38) and (39).

(38) A: Il fatto che ci sono delle imagini, che ci sono delle cose, non ti aiuta a capire la parola meggioremente che in un testo?

B: Si. Quello sicuramente.

A: 'Doesn't the fact that there are images, that there are things, help you to understand the word better than in a text?'

B: 'Yes it does, definitely [lit. this surely].'

\begin{tabular}{|l||l|l|l|}
\hline 1 & A: & $\begin{array}{l}\text { il fatto che ci sono delle immagini } \\
\text { 'the fact that there are images' }\end{array}$ & $\begin{array}{l}\text { che ci sono delle cose } \\
\text { 'that there are things' }\end{array}$ \\
\cline { 3 - 4 } 2 & \multirow{2}{*}{ B: } & & $\begin{array}{l}\text { non ti aiuta a capire la parola maggiormente } \\
\text { che in un testo? } \\
\text { 'doesn't it help you to understand a word } \\
\text { better than in a text?' }\end{array}$ \\
\hline 4 & & $\begin{array}{l}\text { si } \\
\text { 'yes' }\end{array}$ \\
\cline { 3 - 4 } & $\begin{array}{l}\text { quello } \\
\text { 'this' }\end{array}$ & $\begin{array}{l}\text { sicuramente } \\
\text { 'surely' }\end{array}$ \\
\hline & PREFIX & NUCLEUS \\
\hline
\end{tabular}


(39) A: Chi viene?

B: Beh, l'Anna ci sarà. La Patrizia adesso sentirò. Dema e Gigi, sicuramente!

A: 'Who is coming?'

B: 'Well, Anna will be there. Patrizia, I will call her now. Dema and Gigi for sure [lit. Dema and Gigi surely].'

\begin{tabular}{|l||l|l|l|l||}
\hline 1 & A: & & & $\begin{array}{l}\text { chi viene? } \\
\text { 'who is coming?' }\end{array}$ \\
\hline 2 & \multirow{2}{*}{ B: } & $\begin{array}{l}\text { beh } \\
\text { 'well' }\end{array}$ & $\begin{array}{l}\text { l'Anna } \\
\text { 'Anna' }\end{array}$ & $\begin{array}{l}\text { ci sarà } \\
\text { 'will be there' }\end{array}$ \\
\cline { 3 - 5 } 3 & & $\begin{array}{l}\text { la Patrizia } \\
\text { 'Patrizia' }\end{array}$ & $\begin{array}{l}\text { adesso sentirò } \\
\text { 'I will call her now' }\end{array}$ \\
\cline { 3 - 5 } & & & $\begin{array}{l}\text { Dema e Gigi } \\
\text { 'Dema and Gigi' }\end{array}$ & $\begin{array}{l}\text { sicuramente } \\
\text { 'surely' }\end{array}$ \\
\cline { 3 - 5 } & & & PREFIX & NUCLEUS \\
\hline & & & & \\
\hline
\end{tabular}

In this construction sicuramente realizes a focalized NUCLEUS preceded by a PREFIX that indicates the domain of application of the judgment expressed by sicuramente. Such a PREFIX has the semantic, syntactic and prosodic features of what has been called in the literature a 'contrastive topic' (Kuno 1976; Büring 1999; Frascarelli \& Hinterhölz 2007; Puglielli \& Frascarelli 2007; Mereu \& Trecci 2004), i.e. a topic that creates oppositional pairs with other topics. As such, this PREFIX evokes a paradigm of other objects to which the judgment sicuramente does not apply.

The construction PREFIX-[sicuramente] $]_{\text {NUCLEUS }}$ is thus made up of two elements, each evoking a paradigm of alternative options: on the one hand the presence of a focalized sicuramente in the NUCLEUS position evokes a paradigm of other possible judgments (see $\S 6.2$ ); on the other hand a contrastive topic in the PREFIX serves the purpose of calling to mind a paradigm of alternative objects of the judgment. The result is the expression of a restricted commitment of the speaker. The speaker says that something is sure, but saying that evokes the fact there are many other things which are much less sure. He thereby restricts his commitment to the object described in the prefix. Example (40) shows that such a function cannot be fulfilled by certamente, which is not compatible with paradigms of alternative judgments and which therefore cannot occur in such a construction:

(40) A: Chi viene?

B: ? Beh, l'Anna ci sarà. La Patrizia, adesso sentirò. Dema e Gigi, certamente.

To sum up, sicuramente, unlike certamente, can occur in the construction PREFIX-[sicuramente] $]_{\text {NUCLEUS, }}$ in which sicuramente realizes a focalized NUCLEUS 
position, introduced by a contrastively focalized PREFIX. In this construction sicuramente expresses a strong commitment limited to the truth of the object in the PREFIX and evoking other objects to whose truth the speaker is not committed.

\subsection{Triggering a paradigm of alternative judgments}

To sum up this section, sicuramente can occur in three monophonic MDCs that realize or evoke paradigms of alternative judgments: it can realize the final position in monological monophonic lists of NUCLEI, it can occur in the syntactic focus position and in particular it can realize on its own a focalized NUCLEUS introduced by a contrastive PREFIX. Certamente is unsuitable in all these MDCs. This suggests that sicuramente should be understood as an adverb triggering a paradigm of alternative monophonic judgments, whereas certamente does not have such a function.

\section{Conclusions}

The data analyzed in this article show that, in spite of their near-synonymy, certamente and sicuramente select different distributional contexts at the level of discourse. The asymmetry of the syntactic distribution mirrors a semantic asymmetry. Certamente occurs in contexts that highlight its semantic nature as a polyphonic trigger. By contrast, sicuramente occurs in contexts that reveal its nature as a trigger of a paradigm of strictly internal alternative judgments. These results allow some of the questions asked in $\$ 2$ to be answered.

Firstly, in Italian there are at least two adverbs specialized in marking some of the discursive and dynamic aspects of commitment. Sicuramente, as a trigger of alternative judgments, serves the function of marking either the progression of commitment or its restriction to a limited domain of application. Certamente, as a polyphonic trigger, marks a commitment to the truth of a content that is expressed in agreement or in opposition to other discursive voices.

Secondly, the encoding of the more discursive and dynamic aspects of commitment takes place, at least in this case, not at the morphological or at the syntactic level, but at the discourse level. Indeed, it is conveyed by the constructional composition of the lexical meaning of the two adverbs with the meaning of the discourse structures with which they are associated.

\section{Open questions: toward a redefinition of epistemic modality.}

A third question was raised in $\S 2$. Are the markers expressing the more discursive and dynamic aspects of commitment grammatical or lexical? At first glance one would be tempted to answer without hesitation that they are adverbs and therefore lexical markers. Nevertheless another interpretation is possible. 
The fact that the two adverbs are regularly associated with MDCs characterized by well-defined topological structures could be interpreted as a reduction of their syntagmatic autonomy. If we accept that 'grammaticalization detracts from autonomy' (Lehmann 1985), a weak form of incipient grammaticalization could be postulated for these forms. The exploration of such a hypothesis goes beyond the scope of the present paper, so the question of the grammatical nature of the dynamic and discursive aspects of commitment will be addressed in future research. Nevertheless, it is clear that the hypothesis that some discursive and dynamic aspects of commitment may be grammaticalized at least to a certain extent paves the way for a redefinition of epistemic modality as the grammatical category that not only expresses, but also constructs the commitment of the speaker in discourse.

\section{pietrand@uniroma3.it}

\section{Notes}

${ }^{1}$ The most classical example provided in the literature to show that utterances do signal the layering of discursive voices expressing different points of view is the following:

(a) This wall is not white

Two different voices and two different points of view coexist within this utterance. The first voice coincides with a speaker who expresses his point of view: 'the wall is not white'. The use of the negation evokes another, not explicitly quoted, discursive voice that has expressed the point of view 'the wall is white'.

${ }^{2}$ There are some marginal exceptions to this generalization. Some speakers, for example, would accept that certamente could occur in this position in some futural contexts. For this reason, example (1f) has been marked with a question mark rather than an asterisk.

${ }^{3}$ See below (\$4.2) for a definition of macro-syntax.

${ }^{4}$ The translations provided in the grids are deliberately as literal as possible in order to facilitate the grid representation.

${ }^{5}$ For example, the DC in (5) is characterized by two lists of arguments in the ARG1 and ARG2 positions, a repetition of a syntactic structure (line 1 and line 2) and a chiasmus between the first two realizations of the ARG1 and ARG2 positions. The pre-verbal hyperonym in ARG1-line1 position per ogni tipo di gioco 'for every kind of game' is exemplified by a post-verbal hyponym in ARG2-line2 alle corse dei carri 'for the chariot races', whereas the post-verbal hyperonym in ARG2-line1 position un edificio specifico 'a specific building' is exemplified by a pre-verbal hyponym in ARG1-line2 il circo 'the circus'. (Bonvino 2005: 61).

${ }^{6}$ Interestingly, the relative position of certamente with respect to the nucleus in which the speaker repeats what has been said by someone else is not indifferent. MDCs such as (14'), in which certamente follows the repetition, may acquire concessive overtones. MDCs such as (15) and (16), where certamente precedes the repetition cannot acquire such an overtone.

${ }^{7}$ The grid representation of (20') displays not only the macro-syntactic structure of the MDC, but also its predicate-argument-adjunct structure. The reason for this representational choice lies in the fact that, as will be made clearer later, the repetition of the predicate-argument-adjunct structure conveys per se part of the overall meaning of the MDC. 


\section{References}

Andersen, H.L. \& Nølke, H. (eds) 2002. Macro-syntaxe et macro-sémantique, Actes du colloque international d'Arhus, 17-19 mai 2001. Bern: Peter Lang.

Baroni, M., Bernardini, S., Comastri, F., Piccioni, L., Volpi, R., Aston \& G., Mazzoleni, M. 2004. "Introducing the "La Repubblica" corpus: A large, annotated, TEI(XML)-compliant corpus of newspaper italian". In Proceedings of the 4th International Conference on Language Resources and Evaluation, Lisbon, May 2628, 2004. Paris: ELRA, pp. 1771-1774.

Berrendonner, A. 1990. "Pour une macro-syntaxe". Travaux de linguistique 21: 25-31.

Beyssade, C. \& Marandin, J.-M. forthcoming. "Commitment: attitude propositionnelle ou attitude dialogique?". Langue française.

Bilger M., Blasco, M., Cappeau, P., Sabio, F. \& Savelli, M.-J. 1997. "Transcription de l'oral et interprétation: illustration de quelques difficultés". Recherches sur le français parlé 14: 55-85.

Bilger, M. 1982. "Contribution à l'analyse en grille". Recherches sur le français parlé 4: $195-215$.

Blanche-Benveniste, C. 1993. "Répétitions de lexique et glissement vers la gauche". Recherches sur le français parlé 12: 9-34.

Blanche-Benveniste, C. 1997. Approches de la langue parlée en français. Paris: Ophrys.

Blanche-Benveniste, C., Borel, B., Deulofeu, J., Durand, J., Giacomi, A., Loufrani, C., Meziane, B. \& Pazery, N. 1979. "Des grilles pour le français parlé". Recherches sur le français parlé 2: 163-205.

Blanche-Benveniste, C., Bilger, M., Rouget, Ch., \& van den Eynde, K. 1990. Le français parlé. Etudes grammaticales. Paris: Editions du CNRS.

Bonvino, E. 2005. Le sujet postverbal en italien parlé: syntaxe, zones et intonation. Paris: Ophrys.

Bonvino, E. \& Masini, F. 2007. "Verso una tipologia delle costruzioni di discorso". Università Roma Tre, Ms.

Bonvino, E., Frascarelli, M. \& Pietrandrea, P. 2007. "Semantica, sintassi e prosodia di alcune espressioni avverbiali nel parlato spontaneo". In F. Albano Leoni, A. Giannini, M. Pettorino \& R. Savy (eds), Atti del Convegno Internazionale "La comunicazione parlata" (Naples, February, 23-25 2006). Naples: Liguori.

Branca-Rosoff, S. 1990. "Des grilles pour l'histoire du français écrit?". Recherches sur le français parlé 10: 111-129.

Büring, D. 1999. "Topic". In P. Bosch \& R. van der Sandt (eds), Focus - Linguistic Cognitive and Computational Perspectives. Cambridge: CUP, pp. 142-165.

Cinque, G. 1993. "A Null Theory of Phrase and Compound Stress". Linguistic Inquiry 24: 239-298.

Coates, J. 1983. The Semantics of Modal Auxiliaries. London: Croom Helm.

Cresti, E. 2000. Corpus di italiano parlato. Florence: Accademia della Crusca.

De Mauro, T., Mancini, F., Vedovelli, M. \& Voghera, M. (eds) 1993. Lessico di frequenza dell'italiano parlato. Milan: Etaslibri.

Dendale, P. 2006. "Three linguistic theories of Polyphony/Dialogism: an external point of view and comparison”. Sproglig polyfoni. Arbejdspapirer 5: 3-32. 
Dendale, P. \& Coltier, D. 2006. "Eléments de comparaison de trois théories linguistiques de la polyphonie et du dialogisme". In L. Perrin (ed), Le sens et ses voix. Dialogisme et polyphonie en langue et en discours. Recherches Linguistiques, 28. Metz: Université PaulVerlaine, pp. 271-299.

Dendale, P. \& van der Auwera, J. (eds) 2001. Les verbes modaux. Cahiers Chronos, 8. Amsterdam/Atlanta: Rodopi.

Desclés, J.-P. 2007. "Prise en charge énonciative, engagement, désengagement. Vers une carte sémantique". Paper presented at the International Conference on the Notion of Commitment in Linguistics. Antwerp, January 2007.

Desclés, J.-P. \& Guentchéva, Z. 2001. "Enonciateur, locuteur, médiateur”. In A. Becquelin \& P. Erickson (eds), Les rituels du dialogue. Paris: L'Harmattan, pp. 79-112.

Ducrot, O. 1984. Le dire et le dit. Paris: Les éditions de Minuit.

Ducrot, O. 2001. "Quelques raisons de distinguer « locuteurs » et «énonciateurs »". In Polyphonie linguistique et littéraire, Documents de travail 3: 19-41.

Duvallon, O. 2006. Le pronom anaphorique et l'architecture de l'oral en finnois et en français. Paris: L'Harmattan.

Frascarelli, M. \& Hinterhölz, R. 2007. "Types of topics in German and Italian". In S. Winkler \& K. Schwabe (eds), On Information Structure, Meaning and Form. Amsterdam/Philadelphia: Benjamins, pp. 87-116.

Frawley, W. (ed) 2006. The Expression of Modality. Berlin: Mouton de Gruyter.

Gazdar, G. 1981. "Speech Act Assignment". In A.K. Joshi, B.L. Webber and I.A. Sag (eds), Elements of Discourse Understanding. Cambridge: CUP, pp. 64-83.

Gunlogson, C. 2003. True to Form: Rising and Falling Declaratives as Questions in English. New York: Routledge.

Hamblin, C.L. 1970. Fallacies. London: Methuen.

Hamblin, C.L. 1971. "Mathematical models of dialogue". Theoria 37: 130-155.

Harris, Z. 1968. Mathematical structures of language. New York: Wiley-Interscience.

Heim, I. 1982. The Semantics of Definite and Indefinite Noun Phrases. PhD thesis, University of Massachusetts, Amherst.

Kamp, H. 1981. "A theory of truth and semantic representation". In J. Groenendijk, T. Janssen \& M. Stokhof (eds), Formal Methods in the Study of Language. Amsterdam: Mathematical Centre Tracts 135 pp. 277-322.

Kuno, S. 1976. "Subject, theme, and the speaker's empathy. A re-examination of relativization phenomena". In Ch. N. Li (ed), Subject and Topic. New York: Academic Press, pp. 417-444.

Laurendeau, P. 1989. "Repérage énonciatif et valeur de vérité: la prise en compte, la prise en charge". In D. Vincent \& D. Saint-Jacques (eds), Des analyses de discours, Actes du CÉLAT, $n^{\circ}$ 2, mars. Québec: Publications du CÉLAT, Université Laval, pp. 107-129.

Lehmann, C. 1985. "Grammaticalization: synchronic variation and diachronic change". Lingua e Stile XX(3): 303-319.

Lyons, J. 1977. Semantics, Vol 2. Cambridge: CUP.

Mann, W. C. \& Thompson, S. A. 1988. "Rhetorical Structure Theory: toward a functional theory of text organization". Text 8(3): 243-281.

Masini F. \& Pietrandrea, P. in preparation. "Magari". submitted to Cognitive Linguistics. 
Mereu, L. \& Trecci, A. 2004. "Focus sul topic". In F. Albano Leoni, F. Cutugno, M. Pettorino \& R. Savy (eds), Il Parlato Italiano. Atti del Convegno Nazionale (13-15 febbraio 2003). Naples: M. D'Auria Editore - CIRASS.

Muller, C. 2002. "Schèmes syntaxiques dans les énoncés longs: où commence la macro-syntaxe?". In H.L. Andersen \& H. Nølke (eds), Macro-syntaxe et macrosémantique, Actes du colloque international d'Århus, 17-19 mai 2001. Bern: Peter Lang, pp. 71-94.

Nølke, H. 1994. "La dilution linguistique des responsabilités. Essai de description polyphonique des marqueurs évidentiels il semble que et il paraît que". Langue française 102: 84-94.

Nølke, H. 2001. Le regard du locuteur 2. Paris: Kimé.

Nølke, H. \& Olsen, M. 2000. "Polyphonie: théorie et terminologie". Polyphonie linguistique et littéraire 2: 45-169.

Nølke, H., Fløttum, K. \& Norén, C. 2004. ScaPoLine. La théorie scandinave de la polyphonie linguistique. Paris: Kimé.

Nuyts, J. 2001. Epistemic Modality, Language, and Conceptualization. Amsterdam/Philadelphia: Benjamins.

Palmer, F.R. 1986. Mood and Modality. Cambridge: CUP.

Papafragou, A. 2000. Modality: Issues in the Semantics-Pragmatics Interface. CRiSPI, 6. Amsterdam/New York: Elsevier.

Pietrandrea, P. 2005. Epistemic Modality. Functional Properties and the Italian System. Studies in Language, Companion Series 74. Amsterdam/Philadelphia: Benjamins.

Pietrandrea, P. 2007. "The grammatical nature of some epistemic evidential adverbs and adverbial constructions in spoken Italian". Italian Journal of Linguistics 19(1): 31-64.

Polanyi, L. 1988. "A Formal Model of the Structure of Discourse". Journal of Pragmatics 12:601-638.

Polanyi, L., Culy, C., van den Berg, M.H., Thione, G.L. \& Ahn, D. 2004. Proceedings of the ACL2004 Workshop on Discourse Annotation, Barcelona, Spain, July 25-26, 2004.

Puglielli, A. \& Frascarelli, M. 2007. "Interfaces: the relation between structure and output". In E. Pizzuto, P. Pietrandrea \& R. Simone (eds), Verbal and Signed Languages. Comparing Structures, Constructs and Methodologies. Berlin: Mouton De Gruyter, pp. 133:167.

Rooth, M. 1992. "A theory of focus interpretation". Natural Language Semantics 1: 75-116.

Simone, R. 2007. "Constructions and categories". In E. Pizzuto, P. Pietrandrea \& R. Simone (eds), Verbal and Signed Languages. Comparing Structures, Constructs and Methodologies. Berlin: Mouton De Gruyter, pp. 199-249.

Taboada, M. \& Mann, W.C. 2006a. "Rhetorical Structure Theory: looking back and moving ahead". Discourse Studies 8(3): 423-459.

Taboada, M. \& Mann, W.C. 2006b. "Applications of Rhetorical Structure Theory". Discourse Studies 8(4): 567-588.

van der Auwera, J. \& Dendale, P. (eds). 2001. Modal Verbs in Germanic and Romance Languages. Belgian Journal of Linguistics, 14. Amsterdam/Philadelphia: Benjamins. 